\title{
Time Series Analysis of the Relationship between Macroeconomic Factors and the Stock Market Returns in Pakistan
}

\section{Pakistan'daki Makroekonomik Faktörler ve Menkul Kıymetler Getirisi Arasındaki İlişkinin Zaman Serisi Analizi}

\author{
Zaheer Alam, COMSATS Institute of Information Technology, Pakistan, \\ Kashif Rashid, COMSATS Institute of Information Technology, Pakistan, mkrashid@ciit.net.pk
}

\begin{abstract}
The purpose of this research is to investigate the relationship between Karachi stock market 100 index and macroeconomic variables, i.e., inflation, industrial production, money supply, exchange rate and interest rate. The long term relationship between macroeconomic variables and stock market returns has been analyzed by using Johnson Cointegration test, Augmented Dicky Fuller (ADF) and Phillip Perron (PP) tests. The Autoregressive Conditional heteroskedasticity Lagrange Multiplier (ARCH LM) test provided prudent evidence about the presence of heteroskedasticity in the data. The Generalized Autoregressive Conditional heteroskedasticity (GARCH) model was used to find out the relationship between stock returns and the variance of the squared error terms as there was heteroskedastic trend in the data. The results show that the cointegrating relationship exists between stock prices and the macroeconomic variables in Pakistani stock market. The GARCH model showed the significant relationships after mitigating the heteroskedasticity. The consumer price index (CPI), money supply (MS), exchange rates (ER) and interest rates (IR) proved to be negatively associated with the stock returns (SR), while industrial production index (IPI) was found to be positively associated with the stock returns. All the variables were significantly associated to stock market returns except inflation. The investors can use the GARCH results for investment decisions that is the returns are volatile not only due to any happening today but also on the past. The findings suggest that in the long run, the Pakistani stock market is reactive to macroeconomic indicators.
\end{abstract}

Keywords: Stock markets, Pakistan, Macroeconomics and heteroskedasticity

\section{Introduction}

The economic growth of a country largely depends on the development of its financial sector. Stock market is a vital actor of financial sector and provides a platform to the users and suppliers of the financial resources for investment purpose in the stocks of companies. A well-functioning and sound stock market prefers the stocks of successful companies and values more than those of unsuccessful companies. The shares of a successful company are seen to be related to other companies listed in the same stock market. The expected dividend growth and the prices of the shares are well reflected in the stock market.

The stock markets show the volatile behavior over time. In volatility, the prices of shares move up and down in a very short period of time. Excessive volatility is a hurdle in the smooth functioning of financial markets and adversely affects the economies as experienced in the past. This volatility may compel the investors to shift their investments to risk-free assets rather than investing in riskier assets. Therefore, it is necessary for financial analysts, macroeconomists and policy makers to understand the dynamic behavior of stock markets. Most important to note is that the investors are interested in understanding the nature of stock markets behavior as their investment spending is guided by these volatility patterns. The various economic activities of a country influence the returns in the stock market (Liu and Shrestha, 2008). There is a long history of determinants of stock returns in the literature. Different variables are potentially more important in explaining the variations in the stock returns than a single market factor.

Efficient stock markets are critical for the development and growth of any economy. It is the characteristic of this efficient market that it reflects the information in the share prices prevailing in the economy. With increasing globalization process the economies of nations are also globalizing. This global integration is useful for the progression of economies on one end but on the other hand, it has an adverse exposure as the financial disaster of one market leads to the disaster of another market very badly when it is integrated with a big market and disaster originates from that market. The world economy has gained considerable economic growth strength in financial markets. Pakistan has also enjoyed historical performance of the stock market in the last decade. Macroeconomic indicators show the overall strength or weakness of the economy in a country. The most important macroeconomic indicators are Gross Domestic Product, inflation, money supply, interest rates, exchange rates, foreign direct investment and industrial production etc. It is a matter of great interest for academician, researchers, investors, regulators and government bodies to identify impact of macroeconomic 
factors on the stock market. Stock markets being a leading indicator of an economy reflect the level of economic activities in the country. According to Fama (1970) an efficient market is one which reflects relevant information in the share prices. Investors have to determine the intrinsic value of stock by applying fundamental and technical analysis. The analyses of stock returns help them to know the sensitivity of these returns with the macroeconomic variables.

The objectives of the study are as follows:

1. To investigate the impact of macroeconomic factors on stock returns.

2. To investigate the stock market efficiency in Karachi Stock Exchange.

The remainder of this study is organized as follows: Section 2 provides the literature review. Section 3 discusses the methodology for the study. Section 4 describes the results and finally Section 5 concludes.

\section{Literature Review}

In this section, review of the literature on the relationship between stock market returns and macroeconomic variables namely inflation, interest rates, money supply, exchange rate and industrial production has been mentioned.

Acikalin et al. (2008) investigated the relationship between macroeconomic variables and stock returns in Istanbul Stock Exchange (ISE). Four macroeconomic variables i.e., Gross Domestic Product, interest rate, exchange rate and current account balance were used as independent variables and Istanbul stock index was used as the dependent variable. Time series quarterly data was obtained for all the variables. By applying Johnson Cointegration and Vector Error Correction model on the quarterly data they found a long term and stable relationship between ISE index and macroeconomic variables. By using causality test it was discovered that there existed uni-directional causation between macro indicators and ISE index.

Gunsel \& Cukur (2007) analyzed the effect of macroeconomic factors on the London stock returns for the period between 1980 and 1993. They developed seven prespecified macroeconomic variables. The term structure of interest rate, the risk premium, the exchange rate, the money supply and unanticipated inflation, sectoral dividend yield and sectoral unexpected production were used as independent variables and London stock returns as the dependent variable. The results indicate that macroeconomic factors have a significant effect in the U.K stock exchange market however; each factor may affect different industry in a different manner. That is, a macroeconomic factor may affect one industry positively, but affect the other industry negatively.

Chen et al. (2005) investigated the relationship between macro and non-macroeconomic factors and the hotel stock returns on the Taiwan stock exchange. Money supply, the growth rate of industrial production, expected inflation, the change of unemployment rate, and the yield spread were taken as macroeconomic variables. On the contrary, presidential elections, the 9/21 earthquake, the 2003 Iraqi war, the outbreak of SARS, sports megaevents, the Asian financial crisis, and the 9/11 terrorist attacks were considered as non-macroeconomic factors. Among the macroeconomic factors only money supply and the unemployment rate significantly explained the movement of hotel stock returns. All the non-macroeconomic factors had a significant influence on the stock returns.

Liu and Shrestha (2008) investigated the long term relationship between the macroeconomic factors and the stock returns in Chinese market. They used exchange rate, inflation, money supply, industrial production and interest rate as independent variables and stock exchange indices as a dependent variable. By using the heteroskedastic cointegration they found the long term relationship between the macroeconomic factors and the stock returns. Industrial production and money supply were positively associated with the stock returns while inflation, exchange rate and interest rate were negatively associated with the stock returns. Chinese stock market was found as reactive to the macroeconomic information.

Mukherjee and Naka (1995) worked on a "Vector Error Correction Model" (VECM) to study the association between stock market returns in Japan and six macroeconomic variables i.e., exchange rate, inflation, money supply, industrial production index, the long-term government bond rate and call money rate. They explored that Japanese stock market was cointegrated with these macroeconomic variables demonstrating a long-term equilibrium relationship between the stock market returns and chosen macroeconomic variables.

Garcia and Liu (1999) studied the determinants of stock market development, the market capitalization. The real income level, saving rate, financial intermediary development, stock market liquidity and macroeconomic stability has been used as important predictors of market capitalization. They used pooled data for a sample of fifteen industrial and developing countries from 1980 to 1995. The real income level, saving rate, financial intermediary development, and stock market liquidity proved to be significantly affecting the stock market development, while macroeconomic stability does not prove significant.

Pal and Mittal (2011) examined the long term relationship between key macroeconomic variables and the Indian capital markets. They attempted to explore how Indian stock market reacts to different macroeconomic variables. Macroeconomic variables such as interest rates, inflation rate, exchange rates and gross domestic savings (GDS) of Indian economy were used as independent variables and two popular stock indices of India 
i.e., BSE (30 share) SENSEX and S\&P CNX Nifty (50 Shares) have been taken as the dependent variable. Quarterly time series data from January 1995 to December 2008 had been used.

The unit root test, the co-integration test and error correction mechanism (ECM) had been applied to derive the long run and short-term relationship. The findings of the study showed that there is a co-integration relationship between macroeconomic variables and Indian stock indices which is indicative of a long-run relationship.

Brooks and Tsolacos (1999) studied the impact of economic and financial factors on the UK property performance using VAR (vector autoregressive model). The results indicated that there existed a significant relationship between unexpected inflation, interest rate spread, unemployment rate and property returns.

\subsection{Conceptual Framework}

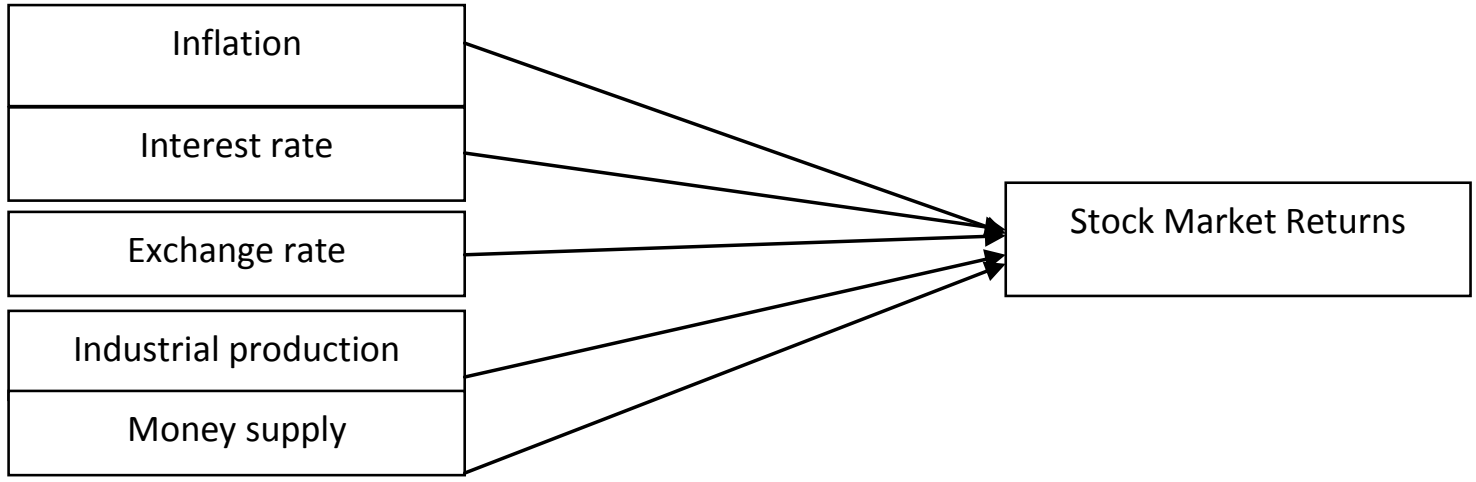

The conceptual framework shows the relationship of independent variables with the dependent variable. The inflation (measured as consumer price index) interest rate, exchange rate, industrial production index and money supply are the independent variables and the KSE 100 index used as a proxy for stock market return is the dependent variable in our study.

\subsection{Hypotheses for the Study}

H1: Inflation has a negative relationship with the stock market returns.

$\mathrm{H} 2$ : Interest rate has a negative relationship with the stock market returns.

H3: Exchange rate has a negative relationship with the stock market returns.

H4: Industrial production has a positive relationship with the stock market returns.

H5: Money supply has a positive relationship with the stock market returns.

\section{Data and Methodology}

Data for the stock returns was collected on the monthly basis from Karachi Stock Exchange for the period of eleven years from 2001 to 2011. The data on macroeconomic factors was collected from the State Bank of Pakistan, and the various Issues of Economic Survey of Pakistan. Karachi Stock Exchange-100 index has been used as a dependent variable in the study. Furthermore, inflation measured as consumer price index (CPI), narrowly defined money supply (M2) has been taken as proxy for money supply in the economy, and industrial production index (IPI) has been used as proxy for real activity in Pakistan. Exchange rate of Pakistani rupee to the U.S dollar has been used. The six months treasury bills rate has been used as a proxy for interest rates. All the variables are converted into natural logarithms. E-Views software has been used to test the hypotheses relevant for the study.

The macroeconomic time series data has been found to be non stationary. The regression results obtained from running a simple regression on the non stationary data are un reliable. The cointegration test suggested by Johnson (1990) has been used to overcome this problem. The Augmented Dicky Fuller (ADF) and Philip Perron (PP) unit root tests have also been applied to check the stationarity of the data.

The regression model for this study is presented as follows:

$$
\mathrm{KSE}_{\mathrm{it}}=\alpha+\beta_{1} \mathrm{EXR}_{\mathrm{it}}+\beta_{2} \mathrm{INF}_{\mathrm{it}}+\beta_{3} \mathrm{IPI}_{\mathrm{it}}+\beta_{4} \mathrm{M} 2_{\mathrm{it}}+\beta_{5} \mathrm{IR}_{\mathrm{it}}+\mathrm{ut}
$$

Where KSE is the stock market returns of KSE-100 at time t. $\alpha$ is the constant. $\beta_{1}$ is the slope coefficient of exchange rate at time t. Similarly, $\beta_{2}$ is the coefficient of inflation at time t. $\beta_{3}$ is the slope coefficient of industrial 
production at time t. In addition, $\beta_{4}$ is the slope coefficient of money supply at time t. Finally $\beta_{5}$ is the slope coefficient of interest rate at time $t$ and ut is the error term. The cointegration test involves the following procedure.

$$
\mathrm{y}_{\mathrm{t}}=\alpha_{0}+\alpha_{1} x_{1 \mathrm{t}}+\alpha_{2} x_{2 \mathrm{t}}+\ldots \ldots \ldots \ldots+\alpha_{\mathrm{k}} x_{\mathrm{kt}}+\mathrm{ut}
$$

The cointegration equation shows the cointegrating relationship of all the independent variables with the dependent variable. In the cointegration equation, it is assumed that the each $(\mathrm{k}+1)$ series is stationary and homoskedastic. If the series are heteroskedastic then heteroskedastic cointegrating relationship can be modeled using Generalized Autoregressive Conditional heteroskedasticity (GARCH) model that is:

$\mathrm{yt}=\alpha_{0}+\alpha_{1} x_{1 \mathrm{t}}+\alpha_{2} x_{2 \mathrm{t}}+\ldots \ldots \ldots \ldots \ldots+\alpha_{k} x_{k t}+u_{t,} \quad u_{t} \mid \Omega_{t-1} \sim \operatorname{iid} N(0, h t)$

III

Where yt is the dependent variable. $\alpha_{0}$ is the constant. $\alpha_{1}$ is the slope of a series $x_{1}$ at time t. Similarly, $\alpha_{2}$ is the slope of a series $x_{2}$ at time t. Finally, $\alpha_{k}$ is the slope coefficient of series $x_{\mathrm{k}}$ at time t. ut is the error term. $\Omega$ is the information set. It is expressed that error term $u_{t}$ is not independently distributed with zero mean and constant variance.

$$
h_{t}=w_{0}+w_{1} h_{t-1}+w_{2} h_{t-2}+u_{t-i}^{2}
$$

Equation IV explains the dependency of the variance of the error terms on the past error terms and also on the variances itself. Where $h_{t}$ is the variance of the error term and the variance is dependent on the variance of the error term at time t-1 and dependent on the past error terms too. $w_{0}$ is the error term at time t, $w_{l}$ is the value of the error term at time $\mathrm{t}-1$ and $w_{2}$ is the value of the error term at time $\mathrm{t}-2 . h_{t-1}$ is the variance of the error term at time $\mathrm{t}-1$ and $h_{t-2}$ is the variance of the error term at time $\mathrm{t}-2$. The heteroskedasticity has been checked by using Lagrange Multiplier (LM) test. Granger causality test has also been applied to test the causation among the macroeconomic variables.

\section{The Empirical Results}

\subsection{Descriptive Statistics}

The Table 1 shows the descriptive statistics of the dependent and independent variables.

\begin{tabular}{|c|c|c|c|c|c|c|}
\hline & EXR & INF & IPI & IR & M2 & KSE \\
\hline Mean & 0.231 & 1.23 & 0.73 & 0.025 & 42.90 & 75.62 \\
\hline Median & 0.0539 & 0.9 & -0.25 & 0.02 & 29.7 & 91.57 \\
\hline Maximum & 4.045 & 6.19 & 40.59 & 2.86 & 485.5 & 1512.66 \\
\hline Minimum & -1.93 & -2.27 & -28.39 & -3.12 & -256.3 & $\begin{array}{c}- \\
3312.09 \\
\end{array}$ \\
\hline Std. Dev. & 0.8037 & 1.63 & 11.98 & 0.66 & 90.23 & 673.26 \\
\hline Skewness & 2.5259 & 0.82 & 0.569 & -0.74 & 1.28 & -1.9128 \\
\hline
\end{tabular}

Table 1: Descriptive Statistics for the Dependent and Independent Variables

Where;

EXR: Exchange Rate.

INF: Inflation.

IPI: Industrial Production Index.

IR: Interest rate.

M2: $\quad$ Money Supply and

KSE: Karachi Stock Exchange 100 index.

The table shows that the mean values for Exchange Rate, Inflation, Industrial Production Index, Interest Rate, Money Supply and Karachi Stock Exchange 100 index are 0.231, 1.23, 0.730, 0.025, 42.90 and 75.62 respectively.

\subsection{Unit Root Test Results}

Both the Augmented Dicky Fuller (ADF) and Philip Perron (PP) tests have been applied. The series are found to be difference stationary at level. However, the series are stationary at their first differences. 
Table 2 shows the results of both the Augmented Dicky Fuller and the Philip Perron unit root test at the level of the series.

Table 2: Unit Root Test Results

\begin{tabular}{|l|l|c|c|c|c|}
\hline Variables & $\begin{array}{l}\text { T-Statistics } \\
\text { ADF }\end{array}$ & T-Statistics PP & $\begin{array}{c}\text { Critical } \\
\text { Value 1\% }\end{array}$ & $\begin{array}{c}\text { Critical } \\
\text { Value 5\% }\end{array}$ & $\begin{array}{c}\text { Critical } \\
\text { Value 10\% }\end{array}$ \\
\hline KSE-100 & -1.355819 & -1.393088 & -3.480818 & -2.883579 & -2.578601 \\
\hline EXR & 0.822233 & 0.548128 & -3.480818 & -2.883579 & -2.578601 \\
\hline CPI & -5.847621 & -9.812075 & -3.480818 & -2.883579 & -2.578601 \\
\hline IR & -1.034487 & -1.363917 & -3.480818 & -2.883579 & -2.578601 \\
\hline IPI & -1.636679 & -1.66375 & -3.480818 & -2.883579 & -2.578601 \\
\hline M2 & 3.234970 & 6.812694 & -3.480818 & -2.883579 & -2.578601 \\
\hline
\end{tabular}

The KSE-100 index, exchange rate, interest rate, industrial production index and money supply contain the T-statistics of $-1.35,0.822,-1.03,-1.63$ and 3.23 respectively. These are non stationary at level. The Philip Perron test confirms the results. The T-statistics for both the ADF and PP tests are less than the critical values. Only the consumer price index is stationary at level with the T-statistics of -5.847 and -9.812 being more than the critical values at $1 \%, 5 \%$ and $10 \%$.

Table 3 shows the results of both the Augmented Dicky Fuller and the Philip Perron unit root test at the first differences of the series.

Table 3: Unit Root Test at First Differences

\begin{tabular}{|l|l|c|c|c|c|}
\hline Variables & $\begin{array}{l}\text { T-Statistics } \\
\text { ADF }\end{array}$ & T-Statistics PP & $\begin{array}{c}\text { Critical } \\
\text { Value 1\% }\end{array}$ & $\begin{array}{c}\text { Critical } \\
\text { Value 5\% }\end{array}$ & $\begin{array}{c}\text { Critical } \\
\text { Value 10\% }\end{array}$ \\
\hline KSE-100 & -10.47840 & -10.46415 & -3.480818 & -2.883579 & -2.578601 \\
\hline EXR & -6.566767 & -6.663224 & -3.480818 & -2.883579 & -2.578601 \\
\hline CPI & -14.33351 & -59.48762 & -3.480818 & -2.883579 & -2.578601 \\
\hline IR & -9.564416 & -9.610338 & -3.480818 & -2.883579 & -2.578601 \\
\hline IPI & -3.650120 & -14.62427 & -3.480818 & -2.883579 & -2.578601 \\
\hline M2 & -6.690802 & -15.18462 & -3.480818 & -2.883579 & -2.578601 \\
\hline
\end{tabular}

The trace statistics of both the ADF and Phillip Perron tests show that all the variables (inflation, KSE-100 index, exchange rate, interest rate, industrial production index and money supply) are stationary at their first difference. The variables like KSE-100, EXR, CPI, IR, IPI and M2 contain the T-statistics of -10.47. -6.56, $14.33,-9.56,-3.65$ and -6.69 respectively which are more than the critical values at $1 \%, 5 \%$ and $10 \%$. The Philip Perron test confirms the results of ADF test. All the series contain a single unit root. The cointegration test can be applied on the data as the series are stationary at the first differences.

Table 4 shows the cointegration test results of KSE-100 returns with the Consumer Price Index.

Table 4: Cointegration Test of KSE-100 Returns with Consumer Price Index

\begin{tabular}{|c|c|c|c|c|}
\hline \multicolumn{5}{|c|}{ Unrestricted Cointegration Rank Test (Trace) } \\
\hline Hypothesized & & Trace & 0.05 & \\
\hline No. of CE(s) & Eigen value & Statistic & Critical Value & Prob.** \\
\hline None $*$ & 0.141313 & 24.26997 & 12.32090 & 0.0003 \\
\hline At most $1 *$ & 0.038010 & 4.921441 & 4.129906 & 0.0315 \\
\hline
\end{tabular}

\subsection{Cointegration Results}

\section{Cointegration Test of KSE-100 Returns with Consumer Price Index:}

The trace statistics and p-values of 24.26(0.0003) and 4.92(0.03) depict the long term relationship between the returns and consumer price index at a 5\% significance level. Hence, Johnson cointegration provides the best evidence of existence of long term relationship between these two variables. There is a negative long term relationship between CPI and KSE-100 returns.

Table 5 shows the cointegration test results of KSE-100 index returns with the interest rates. 
Table 5: Cointegration Test of KSE-100 with Interest Rate (Risk Free Rate)

\begin{tabular}{|c|c|c|c|c|}
\hline \multicolumn{4}{|l|}{ Unrestricted Cointegration Rank Test (Trace) } \\
\hline Hypothesized & & Trace & 0.05 & \\
\hline No. of CE(s) & Eigen value & Statistic & Critical Value & Prob.** \\
\hline None * & 0.129538 & 31.41854 & 12.32090 & 0.0000 \\
\hline At most $1 *$ & 0.102963 & 13.79962 & 4.129906 & 0.0002 \\
\hline Trace test indicates 2 cointegrating eqn(s) at the 0.05 level \\
\hline
\end{tabular}

\section{Cointegration Test of KSE-100 with Interest Rate (Risk Free Rate):}

The normalized cointegrating coefficient of IR with KSE is -2.398. Trace statistics show the existence of cointegrating equations that depict a long term relationship between returns and risk free rate. The T-statistics of 31.41 and 13.79 are more than the critical values at $5 \%$ level of significance.

Table 6 shows Cointegration Test results of KSE-100 index returns with the Exchange Rate.

Table 6: Cointegration Test of KSE-100 with Exchange Rate

\begin{tabular}{|c|c|c|c|c|}
\hline \multicolumn{5}{|l|}{ Unrestricted Cointegration Rank Test (Trace) } \\
\hline Hypothesized & & Trace & 0.05 & \\
\hline No. of CE(s) & Eigen value & Statistic & Critical Value & Prob.** \\
\hline None $*$ & 0.157855 & 34.52406 & 12.32090 & 0.0000 \\
\hline At most $1 *$ & 0.097149 & 12.87688 & 4.129906 & 0.0004 \\
\hline \multicolumn{6}{|c|}{ Trace test indicates 2 cointegrating eqn(s) at the 0.05 level } \\
\hline * denotes rejection of the hypothesis at the 0.05 level \\
\hline
\end{tabular}

\section{Cointegration Test of KSE-100 with Exchange Rate}

Exchange rate and KSE-100 index showed the existence of a long term relationship between the two variables. The null hypothesis that there is a lack of long term relationship between the two variables is rejected. Both the trace statistics i.e., 34.52 and 12.87 are more than the critical values. There is a presence of the long term relationship between exchange rate and KSE-100 index. The cointegrating coefficient of exchange rate with KSE-100 returns is -4.245 .

Table 7 shows the Cointegration Test results of KSE-100 index returns with the Industrial Production Index.

Table 7: Cointegration Test of KSE-100 with Industrial Production Index

\begin{tabular}{|c|c|c|c|c|}
\hline \multicolumn{5}{|c|}{ Unrestricted Cointegration Rank Test (Trace) } \\
\hline Hypothesized & & Trace & 0.05 & \\
\hline No of $\mathrm{CE}(\mathrm{s})$ & Eigen value & Statistic & Critical Value & \\
\hline None * & 0.311038 & 62.09298 & 12.32090 & 0.0000 \\
\hline At most $1 *$ & 0.113285 & 15.14925 & 4.129906 & 0.0001 \\
\hline \multicolumn{5}{|c|}{ Trace test indicates 2 cointegrating eqn(s) at the 0.05 level } \\
\hline
\end{tabular}

Cointegration Test of KSE-100 with Industrial Production Index:

Two cointegrating equations exist between KSE-100 returns and industrial production index proved by the Tstatistics of 62.09 and 15.14 being more than the critical values. It is strongly evidenced that long term relationship exists between these two variables. The direction of relationship was found to be positive. The long term relationship was found significant at $5 \%$ significance level. The cointegrating coefficient of IP with KSE100 is 0.233 .

Table 8 shows the cointegration results of the KSE-100 index returns with the M2.

Table 8: Cointegration Result of KSE-100 with Money Supply Unrestricted Cointegration Rank Test (Trace)

\begin{tabular}{|l|l|l|l|l|}
\hline Hypothesized & & Trace & 0.05 & \\
\hline
\end{tabular}




\begin{tabular}{|c|c|c|c|c|}
\hline No. of CE(s) & Eigen value & Statistic & Critical Value & Prob.** \\
\hline None $*$ & 0.164120 & 22.76730 & 11.22480 & 0.0003 \\
\hline At most $1 *$ & 0.051487 & 6.713170 & 4.129906 & 0.0114 \\
\hline Trace test indicates 2 cointegrating eqn(s) at the 0.05 level \\
\hline * denotes rejection of the hypothesis at the 0.05 level
\end{tabular}

Cointegration Result of KSE-100 with Money Supply

The cointegration results for KSE-100 index and money supply (M2) also showed the strong existence of the long term relationship between KSE-100 index and money supply as suggested by the trace test. The T-statistics of 22.76 and 6.71 are more than the critical values at 5\% level of significance. The p-values are 0.0003 and 0.0114 at level and at lags. The relationship has been found to be negative in the long run. The cointegrating coefficient of money supply is negative with KSE-100 returns.

Table 9 shows the cointegrating coefficients as obtained from the cointegration results of all the independent variables with the dependent variable. The signs attached to the coefficients show the positivity or negativity of the relationship in the long run. These have been separated from the E-Views generated results of the cointegration.

Table 9: Normalized Cointegrating Coefficients (Standard Error in Parenthesis)

\begin{tabular}{|c|c|c|c|c|c|}
\hline KSE & CPI & IR & EXR & IPI & M2 \\
\hline 1.00000 & -1.119313 & -2.398080 & -4.245841 & 0.233254 & -2.404248 \\
\hline SE & $(1.07847)$ & $(1.02137)$ & $(1.05642)$ & $(0.07651)$ & $(0.62773)$ \\
\hline
\end{tabular}

\subsection{Granger Causality Test}

In the time series data there may be a situation when something happening causes another thing to happen later. In other words, events in the past can cause events to happen today. This is why the Granger causality test is applied on the time series. The Table 10 shows the results of Granger causality test with the acceptance or rejection of the null hypothesis of Granger causality.

Table 10: Granger Causality Test

\begin{tabular}{|l|l|c|}
\hline Null Hypothesis & Prob. & Accepted/Rejected \\
\hline INF does not Granger Cause EXR & 0.0004 & Rejected \\
\hline EXR does not Granger Cause INF & 0.4665 & Accepted \\
\hline KSE does not Granger Cause EXR & 0.0062 & Rejected \\
\hline EXR does not Granger Cause KSE & 0.0007 & Rejected \\
\hline IPI does not Granger Cause INF & 0.0376 & Rejected \\
\hline INF does not Granger Cause IPI & 0.0655 & Rejected \\
\hline KSE does not Granger Cause INF & 0.0090 & Rejected \\
\hline INF does not Granger Cause KSE & 0.0340 & Rejected \\
\hline KSE does not Granger Cause IPI & 0.0098 & Rejected \\
\hline IPI does not Granger Cause KSE & 0.0830 & Rejected \\
\hline M2 does not Granger Cause KSE & 0.1483 & Accepted \\
\hline KSE does not Granger Cause M2 & 0.0032 & Rejected \\
\hline KSE does not Granger Cause IR & 0.3103 & Accepted \\
\hline IR does not Granger Cause KSE & 0.3215 & Accepted \\
\hline M2 does not Granger Cause EXR & 0.0448 & Rejected \\
\hline EXR does not Granger Cause M2 & 0.2372 & Accepted \\
\hline
\end{tabular}

It has been observed that most of the macroeconomic variables Granger cause each other. The null hypothesis of no Granger causality has been rejected in case of the most of the macroeconomic variables.

\subsection{The ARCH LM Test}

The Table 11 shows the results of ARCH heteroskedasticity test. In the conventional econometrics, it is assumed that variance of the disturbance terms remains constant over time. In other words it is assumed that the series is homoskedastic. 
Test Equation:

Table 11: The ARCH LM Test

Dependent variable: $\operatorname{Resid}^{\wedge} 2$

Method: Least Square

Included Observations: 127 after adjustments

\begin{tabular}{|c|r|r|r|r|}
\hline F-statistic & \multicolumn{2}{|c|}{ Prob. F-stat } & 0.0006 \\
\hline Obs*R-squared & 20.64957 & \multicolumn{2}{|c|}{ Prob. Chi square(5) } & 0.0009 \\
\hline Variable & Coefficient & Std. Error & t-Statistic & Prob. \\
\hline C & $2.22 \mathrm{E}+25$ & $1.79 E+25$ & 1.239832 & 0.2174 \\
\hline RESID^2(-1) & 0.438306 & 0.090908 & 4.821405 & 0.0000 \\
\hline R-Squared & 0.162595 & Akaike info criterion & 123.9505 \\
\hline Adjusted R-Sq & 0.127992 & Schwarz criterion & 124.0849 \\
\hline F-Statistics & 4.698801 & Hannan-Quinn criter. & 124.0051 \\
\hline Prob(F.Statistics) & 0.000589 & Durbin-Watson stat & 2.000160 \\
\hline
\end{tabular}

The ARCH heteroskedasticity test highly rejects the null hypothesis. The results show the presence of heteroskedasticity. The computation of $\mathrm{T}$ times $\mathrm{R} 2$ (obs*R-squared) is 20.649 which is greater than the critical value of chi-square at k-1 degrees of freedom, as critical value is 11.07 . That is (LM-stats $>\chi 2 p-1, \alpha)$. The pvalue of chi-square is 0.0009 which is lower than the critical value of 0.05 . The residual square at -1 takes the coefficient of 0.4383 and is highly significant with the $p$-value 0.0000 . The (T $x$ R) value being greater than $\chi 2 p$ 1 and the p-value being less than 0.05 mean the massive rejection of the null hypothesis. The table shows ARCH (1) effect only. The ARCH effect can be estimated on more than one lag. That case will be ARCH (1), ARCH (2), ARCH (3) and so forth.

The Akaike-information criteria have been used for the selection of lags that suggests only one lag. The tstatistic of the unit root test on the residuals is -11.06 which shows that the series is stationary at level with the pvalue of 0.0000 that is highly significant. Hence, it is concluded that $\mathrm{ARCH}$ effect is present in the data proving the presence of heteroskedasticity. This means that there is volatility clustering in the data. For computing LM test, the auxiliary regression is computed first with the $\operatorname{Resid}^{\wedge} 2$ as dependent variable and all the explanatory variables as the independent variables. The ARCH LM test shows the presence of ARCH effect.

Dependent Variable: KSE

Table 12: The GARCH $(1,1)$ Test

Included observations: 132 after adjustments

Convergence achieved after 66 iterations

$\mathrm{GARCH}=\mathrm{C}(7)+\mathrm{C}(8) * \operatorname{RESID}(-1)^{\wedge} 2+\mathrm{C}(9) * \mathrm{GARCH}(-1)$

\begin{tabular}{|c|c|c|c|c|}
\hline Variable & Coefficient & Std. Error & Z-Statistics & Probability \\
\hline $\mathrm{C}$ & 0.040043 & 0.007304 & 5.482350 & 0.0000 \\
\hline CPI & -0.045442 & 0.661345 & -0.068711 & 0.9452 \\
\hline EXR & -1.422695 & 0.004775 & -0.817127 & 0.0000 \\
\hline IPI & 0.107050 & 0.086488 & 1.237747 & 0.2158 \\
\hline IR & -0.051288 & 0.062766 & -0.817127 & 0.4139 \\
\hline M2 & -0.331654 & 0.331455 & -1.000600 & 0.3170 \\
\hline \multicolumn{5}{|l|}{ Variance Equation: } \\
\hline $\mathrm{C}$ & $2.98 \mathrm{E}-05$ & 0.000110 & 0.271535 & 0.7860 \\
\hline $\operatorname{RESID}(-1)^{\wedge} 2$ & -0.049898 & 0.007942 & -6.283009 & 0.0000 \\
\hline GARCH(-1) & 1.071039 & 0.028416 & 37.69130 & 0.0000 \\
\hline R-Squared & 0.041898 & \multicolumn{2}{|c|}{ Durban Watson Stats } & 1.961190 \\
\hline Adj. R-Squared & 0.003574 & \multicolumn{2}{|c|}{ Akaike info criterion } & 2.150247 \\
\hline
\end{tabular}

\subsection{The GARCH $(1,1)$ Test}

GARCH test has been applied when it has been proven that there is heteroskedastic trend in the data even though the long term relationship among macroeconomic variables and the stock returns have been estimated using the cointegration test. GARCH $(1,1)$ mitigates for the heteroskedasticity in the data and provides the relationship 
among the variables. In case there is volatility clustering in the data GARCH is a powerful tool to be used to further strengthen the evidence of the relationship.

The GARCH equation as obtained from applying the test can be seen in the table 12 where $\mathrm{C}(7)$ is the constant of the equation, $C(8)$ is the coefficient of the squared residuals and $C(9)$ is the coefficient of the variances of the residuals.

The GARCH Table 12 presented above shows the results of GARCH $(1,1)$ test. The GARCH, Generalized Autoregressive Conditional heteroskedasticity test has been applied on the heteroskedastic test after checking for heteroskedasticity by using ARCH LM test for heteroskedasticity. The ARCH heteroskedasticity test shows a higher (Obs*R-squared) value of 20.649 which is greater than the critical value of chi-square at k-1 degrees of freedom that is 11.07 .

The Lagrange Multiplier test showed the presence of heteroskedasticity among the macroeconomic variables. The p-value of chi-square is 0.00000 that is less than the critical p-value of 0.05 . After the rejection of null hypothesis of no heteroskedasticity and the evidence of ARCH effects, the GARCH $(1,1)$ test was applied. The GARCH test detected the heteroskedasticity and showed a very significant long term relationship among the macroeconomic variables and returns. The coefficients of independent variables are reported as the same depicted by Johnson cointegration test and OLS estimates.

The variance equation results of GARCH test are significant at $0.01 \%$ significance level. The GARCH $(1,1)$ test follows the ARCH LM test as post estimation diagnostics and the results of after ARCH test are reliable to heteroskedasticity because the Obs*R-squared value of ARCH test is 2.37 being less than 11.07. The p-value of chi-square 0.1232 is greater than the critical value of chi-square of 0.05 . Hence, it is clearly evidenced that heteroskedasticity in the data has been modeled by the application of GARCH test. The results of ARCH LM test after GARCH are the clear evidence of the fact.

Table 13 shows the ARCH LM post estimation diagnostics.

Table 13 ARCH Post Estimation Diagnostics

\begin{tabular}{|l|l|l|l|}
\hline Obs*R-Squared & 2.373187 & Prob. Chi square(5) & 0.1232 \\
\hline
\end{tabular}

\section{Summary and Conclusion}

This study investigates the impact of macroeconomic variables on Karachi Stock Exchange. Stock market being a leading indicator of an economy has gained much importance in the modern age. By employing cointegration, it has been examined that long term relationship exists between stock market and macroeconomic variables. The industrial production is positively related to the stock market returns (Mehrara, 2006) ${ }^{12}$. The industrial production though small portion of Gross Domestic Product indicates the real activity in the country. On the contrary, inflation is negatively associated to the stock market returns (Pal and Mittal, 2011) ${ }^{13}$. Pakistan is a consumption oriented society and people do not go for the investment in the stocks. Risk free rate is negatively related to the stock market returns (Mukherjee and Naka, 1995) ${ }^{14}$. T-bills are an easy choice for the people when the rate of return is high on T-bills. The exchange rate is found to be negatively associated to the stock market returns (Liu and Shrestha, 2008) ${ }^{15}$. The depreciation of Pakistani rupee causes the stock returns to be lower and vice versa. Money supply is found to be negatively related with the stock market returns. The money supply in Pakistan does not cause economic stimulus and is directly associated with the inflation representing the negative relationship. The study shows that the selected stock market is reactive to the changes in the macroeconomic variables in the long run irrespective of high volatility and immaturity.

The selected market has the characteristics of developing market i.e., low liquidity, concentrated shareholdings, high leverage and low informational and operational efficiency. The study shows that there is an impact of macroeconomic indicators on the stock market.

The stock returns at specific point in time does not depend on a variable at that time but on the happenings of past too. It means that the returns are volatile. The economic indicators can be considered as explaining the stock market behavior.

\section{Limitations}

The current study is limited to the time period between 2001 and 2011. This study is confined to the macroeconomic variables used in the analysis only. More powerful econometric models can be employed to further investigate the long run relationship which will give us new policy implications for the developing market. 


\section{References}

Acikalin, S. Aktas, R. and Unal, S. (2008). Relationships between stock markets and macroeconomic variables: an empirical analysis of the Istanbul Stock Exchange. Investment Management and Financial Innovations, 5(1): 8-16.

Brooks, C. and Tsolacos, S. (1999). The impact of economic and financial factors on the UK property performance. Journal of Property Research, 16(2): 139-152.

Chen, M. Kim, W. and Jeong, K (2005). The impact of macroeconomic and non-macroeconomic forces on hotel stock returns. Hospitality Management, 24: 243-258.

Fama, E. (1970). Efficient capital markets: a review of theory and empirical work. The Journal of Finance, 25(2): 383- 417.

Garcia, V. and Liu, L. (1999). Macroeconomic determinants of stock market development. Journal of Applied Economics, 2(1): 29-59.

Gunsel, N. and Cukur, S. (2007). The effects of macroeconomic factors on the London Stock returns: a sectoral approach. International Research Journal of Finance and Economics, 10: 140-152.

Johnson, D. (1990). Co-Integration, error and purchasing power parity between Canada and the United States. The Canadian Journal of Economics, 23(4) 839-855.

Liu, M. and Shrestha, K. (2008). Analysis of the long term relationship between Macro-economic variables and the Chinese stock market using heteroscedastic cointegration. Journal of Managerial Finance, 34(11): 744-755.

Mehrara, M. (2006). The relationship between stock market and macroeconomic Variables: a case study for Iran. Iranian Economic Review, 10(17): 137-148.

Mukherjee, T. and Naka, A. (1995). Dynamic relations between macroeconomic variables and the Japanese stock market: an application of a vector error correction model. Journal of Financial Research, 18(2): 223-237.

Pal, K. and Mittal, R. (2011). Impact of macroeconomic indicators on Indian capital markets. The Journal of Risk Finance, 12(2): 84-97. 